\title{
Evaluation of mathematical models to describe lamb growth during the pre-weaning phase
}

\section{Avaliação de modelos matemáticos para descrever o crescimento de cordeiros durante a fase de cria}

\begin{abstract}
Antonio Leandro Chaves Gurgel ${ }^{1 *}$; Gelson dos Santos Difante ${ }^{2}$; João Virgínio Emerenciano Neto ${ }^{3}$; Henrique Jorge Fernandes²; Luís Carlos Vinhas Ítavo; Camila Celeste Brandão Ferreira Ítavo²; Patrick Bezerra Fernandes ${ }^{4 ;}$; Bárbara Martins Brixner5; José Igor Gomes Bezerra6; Pedro Henrique Cavalcante Ribeiro ${ }^{6}$
\end{abstract}

\section{Highlights}

Body weight is one of the main information in production systems.

Lambs in the brooding phase have a high capacity for weight gain.

Mathematical models are important tools for decision making.

Four mathematical models were tested to evaluate the lamb growth curve.

Linear models are more efficient to explain the growth curve of crossbred lambs.

\begin{abstract}
The aim of this study was to evaluate the use of different mathematical models to describe the growth of lambs during the pre-weaning phase and the effect of sex on their growth curve. Data from 51 lambs (26 males and 25 females) with a genetic constitution of at least 50\% Santa Inês breed were used. Lamb weight was monitored during the entire pre-weaning phase (91 days) by weighing the animals weekly on a scale suitable for sheep, to draw the body-weight growth curve. The adequacy of the models was evaluated by the coefficient of determination, simultaneous F-test for parameter identity, concordance correlation
\end{abstract}

1 Student of the Doctorate in Animal Science, Faculty of Veterinary Medicine and Animal Science, Federal University of Mato Grosso do Sul, UFMS, Campo Grande, MS, Brazil. E-mail: antonioleandro09@gmail.com

2 Profs. Drs., Postgraduate Program in Animal Science, Faculty of Veterinary Medicine and Animal Science, UFMS, Campo Grande, MS, Brazil. E-mail: gdifante@hotmail.com; henrique.uems@hotmail.com; luis.itavo@ufms.br; camila. itavo@ufms.br

3 Prof. Dr., Postgraduate Program in Animal Science, Campus of Agricultural Sciences, Federal University of Vale do São Francisco, UNIVASF, Petrolina, PE, Brazil. E-mail: joao_neto@zootecnista.com.br

${ }^{4}$ Dr., Animal Science, Faculty of Veterinary Medicine and Animal Science, UFMS, Campo Grande, MS, Brazil. E-mail: zoo.patrick@hotmail.com

${ }^{5}$ Student Master's in Animal Science and Pasture, School of Agriculture Luiz de Queiroz, University of São Paulo, USP, São Paulo, SP, Brazil. E-mail: barbarabrixner@hotmail.com

${ }^{6}$ Graduate Students in Animal Science, Academic Unit Specializing in Agricultural Science, Federal University of Rio Grande do Norte, UFRN, Macaíba, RN, Brazil. E-mail: joseigorbezerra@hotmail.com; pedrohcrib@gmail.com

* Author for correspondence

Received: Sept. 24, 2020 - Approved: Nov. 24, 2020 
coefficient, root mean square error of prediction and decomposition of the mean square error of prediction. Pairwise mean square error of prediction analysis and delta Akaike information criterion were used to compare the models in terms of accuracy and precision. The evaluation of the adequacy of the tested models showed that the data predicted by the linear, quadratic and exponential models were similar $(\mathrm{P}>$ 0.05 ) to the observed data. In contrast, the monomolecular model generated predictions that could not be accepted as true. The linear and quadratic models showed better accuracy and precision. The first-degree linear model should be preferred over the other studied models to describe growth of sheep in the preweaning phase. Males and females exhibited distinct growth patterns.

Key words: Growth curve. Hoggets. Modeling.

\section{Resumo}

Os objetivos foram avaliar o uso de diferentes modelos matemáticos para descrever o crescimento de cordeiros durante a fase de cria e também avaliar o efeito do gênero sobre o curva de crescimento destes cordeiros. Foram utilizados dados de 51 cordeiros, 26 machos e 25 fêmeas, com composição genética de pelo menos $50 \%$ da raça Santa Inês. O peso dos animais foi acompanhado durante toda fase de cria (91 dias) por meio de pesagens semanais em balança própria para ovinos para desenhar a curva de crescimento do peso corporal. A avaliação da adequação dos modelos foi realizada por meio do coeficiente de determinação, teste F simultâneo para identidade dos parâmetros, coeficiente de correlação de concordância, raiz quadrada do quadrado médio do erro da predição e a decomposição do quadrado médio do erro da predição. A análise do quadrático médio da predição pareada e o critério de informação delta de Akaike foram utilizados para comparar os modelos quanto à acurácia e precisão. A avaliação da adequação dos modelos testados mostrou que os dados preditos pelos modelos linear, quadrático e exponencial são semelhantes $(P>0,05)$ aos dados observados. Já o modelo monomolecular gerou predições que não puderam ser aceitas como verdadeiras. Os modelos linear e quadrático apresentaram melhor acurácia e precisão. O modelo linear de primeiro grau deve ser preferido aos demais modelos estudados para descrever crescimento de ovinos na fase de cria. Machos e fêmeas apresentaram padrão de crescimento distinto.

Palavras-chave: Borregos. Curva de crescimento. Modelagem.

Sheep farming is a promising activity in regions with a semi-arid climate, given the great ability of these animals to adapt to those conditions (Gurgel et al., 2020). The Brazilian Northeast stands out for holding approximately $60 \%$ of the national sheep herd (Ribeiro \& Garcia, 2016). This region has a predominance of animals without a defined bred pattern, which are usually the result of crosses with Santa Inês as the maternal breed (D. A. Souza, Selaive-Villarroel, Osório, \& Teixeira, 2013; Ribeiro \& Garcia, 2016).
Most sheep farms in the semi-arid region of northeastern Brazil are family-owned, with an average size of $13 \mathrm{ha}$, producers having low formal education and herds consisting of around 25 head (Hermuche et al., 2013). In this scenario, with limited use of technologies and low investment in infrastructure, it is common for producers not to periodically weigh the herd, which leads to difficulty in controlling the animals' weight development and selling them on a live weight basis (Kopuzlu, Sezgin, Esenbuga, \& Bilgin, 2014; Conrado, Arandas, 
\& Ribeiro, 2015). Body weight estimates, however, are essential in livestock farming due to their direct relationship with the nutritional requirements of the animals (Vieira et al., 2013; Oliveira et al., 2014).

Therefore, alternative low-cost methodologies must be adopted to estimate the growth rate of lambs in systems where the control of animal performance is precarious or non-existent. This would be even more important in the pre-weaning phase, when animals are highly efficient in weight gain (Urbano et al., 2017). Mathematical models thus emerge as important tools to describe the growth pattern of ruminant animals (Fernandes et al., 2012; Conrado et al., 2015; J. S. Souza et al., 2019), especially when they take into account easily obtained variables, such as age. Mathematical growth models constitute a way of summarizing the information contained in a data sequence into some parameters with biological significance (Kopuzlu et al., 2014). Few studies have examined the adequacy of animal growth models for the ovine species.

In view of the above-described scenario, the present study was conducted to examine the use of different mathematical models to describe the growth of lambs during the pre-weaning phase and the effect of sex on the growth curve of these animals.

The study involved data from 51 lambs (26 males and 25 females) with a genetic constitution of at least $50 \%$ Santa Inês breed, from a breeding station of the dam herd of the Forage Crop Research Group of the Federal University of Rio Grande do Norte (553'34" S and $35^{\circ} 21^{\prime} 50^{\prime \prime}$ W). Shortly after lambing, dams and offspring were placed in a maternity paddock where they spent seven days together. Subsequently, the lambs were separated from their mothers to be managed in a controlled suckling system. The lambs were kept on Panicum maximum cv. Massai pastures during the day (from $07.00 \mathrm{~h}$ to 16.00 h) and moved to a shed with collective stalls at night. A concentrate composed of $66.0 \%$ ground maize, $29.5 \%$ soybean meal, $3.0 \%$ mineral salt and $1.5 \%$ soybean oil was available ad libitum to the lambs, with orts kept around $10 \%$. Lamb weight was monitored during the entire pre-weaning phase (from 7 to 91 days of age) by weighing the animals weekly on a scale suitable for sheep (BL300pro LABOREMUS ${ }^{\circ}$ ) with a capacity of $300 \mathrm{~kg}$.

Four mathematical models were evaluated to describe the growth of the lambs, as follows:

1) First-degree (linear) equation: Weight $=a+b$ *age;

2) Second-degree (quadratic) equation: Weight $=a+b$ *age $+c$ *age ${ }^{2}$;

3) Exponential model: Weight $=a$ * $\exp$ (b*age); and

4) Monomolecular model: Weight $=a^{*}$ $\left(1-\exp ^{\left(-b^{*} \text { age }\right)}\right.$,

where Weight $=$ weight of non-fasted lamb $(\mathrm{kg})$; age = days after lambing; ' $a$ ', 'b' and 'c' = model parameters.

Models were fitted and parameters were estimated using the REG (for linear and quadratic models) and NLIN (for exponential and monomolecular models) procedures of the SAS statistical package (SAS University Edition, Sas Institute Inc. Cary, CA, USA).

The following criteria were used to evaluate the models: coefficient of determination (R2) and $F$ test for the identity of the parameters $(\beta 0=0$ and $\beta 1=1)$ of the 
regression of predicted data on observed values; concordance correlation coefficient (CCC); root mean square error of prediction (RMSEP); and the decomposition of the mean square error of prediction (MSEP) into mean error, systematic bias and random error. Models were compared as to their accuracy by pairwise mean square error of prediction (pMSEP) analysis and as to their precision by the delta Akaike information criterion (AIC) (Tedeschi, 2006). All model evaluation and comparison statistics were calculated using Model Evaluation System software version 3.2.2.

Once the model that best described lamb growth was chosen, the effect of sex on their growth curve was evaluated using a 'Dummy' variable, as suggested by Regazzi (2003). The significance level was set at $5 \%$ for all statistical analyses.

All models exhibited average weight estimates and standard deviations of this weight similar to the real data, as well as high coefficients of determination (above 90\%) of the regression of predicted data on observed values (Table 1). The linear, quadratic and exponential models were able to generate predictions similar $(P>0.05)$ to the observed weights $(\beta 0=0$ and $\beta 1=1)$, whereas the monomolecular model generated predictions different from these data $(P<0.05)$.

The CCC also showed that all models exhibited accuracy and precision, since all had a CCC greater than 0.9. The CCC Analysis shows whether the values predicted by the model are accurate and precise at the same time and vary from 0 to 1 , the closer to 1 , the more precise and accurate the model is (Tedeschi, 2006). The analysis of the RMSEP, which allows to know which the average error of the models when predicting the weight of the animals, indicated that the linear and quadratic models presented greater capacity to predict the exact weight of the animal, presenting RMSEP of 0.414 and $0.413 \mathrm{~kg}$, respectively, while the other models presented RMSEP almost twice as high, on average. These RMSEP values of the two linear models point to an error of only $3.6 \%$, on average, in their forecasts.

\section{Table 1}

Evaluation of the adequacy of growth prediction models for lambs in the pre-weaning phase

\begin{tabular}{|c|c|c|c|c|c|c|c|c|c|}
\hline \multirow{2}{*}{ Model } & \multirow{2}{*}{ Mean } & \multirow{2}{*}{ SD } & \multirow{2}{*}{$\mathrm{R}^{2}$} & \multirow{2}{*}{ P-value } & \multirow{2}{*}{ CCC } & \multirow{2}{*}{ RMSEP } & \multicolumn{3}{|c|}{ Decomposition of MSEP (\%) } \\
\hline & & & & & & & ME & SB & RE \\
\hline Linear & 11.35 & 4.35 & 0.992 & 0.991 & 0.995 & 0.414 & 0.021 & 0.054 & 99.93 \\
\hline Quadratic & 11.35 & 4.34 & 0.992 & 0.999 & 0.995 & 0.413 & 0.00 & 0.00 & 100.00 \\
\hline Exponential & 11.39 & 4.18 & 0.978 & 0.782 & 0.983 & 0.775 & 0.233 & 1.80 & 97.97 \\
\hline Monomolecular & 11.14 & 4.78 & 0.963 & 0.015 & 0.976 & 0.992 & 4.42 & 24.96 & 70.63 \\
\hline Observed data & 11.35 & 4.36 & - & - & - & - & - & - & - \\
\hline
\end{tabular}

$\mathrm{SD}$ = standard deviation; $\mathrm{R}^{2}$ = coefficient of determination; $\mathrm{P}$-value = probability value associated with the simultaneous F-test for the identity of parameters $(\beta 0=0$ and $\beta 1=1)$ of the regression of the observed data on the predicted values; $\mathrm{CCC}=$ concordance correlation coefficient; RMSEP = root mean square error of prediction; $\mathrm{MSEP}=$ mean square error of prediction. $\mathrm{ME}=$ mean error; $\mathrm{SB}=$ systematic bias; $\mathrm{RE}=$ random error . 
The decomposition of the mean square error of prediction showed that the linear, quadratic and exponential models had more than $97 \%$ of their deviations attributed to random errors, which does not imply any mean or systematic deficit of these models. In the monomolecular model, however, about $25 \%$ of the deviations were associated with a systematic bias, i.e., a multiplicative error in the predicted values. When most errors are attributed to the mean bias, it means that there is a deficiency in the positioning of the equality line, which can be corrected with an additive correction factor. The systematic error, on the other hand, indicates a fault in the displacement of the line, which can be corrected with a multiplicative correction factor (Tedeschi, 2006).

Lastly, the comparison between the accuracy and precision of the models indicated that the linear and quadratic models did not differ between themselves and were superior $(P<0.05)$ to the others. These analyses also revealed that the monomolecular model showed the least precision and accuracy, losing even to the exponential model.

The linear (linear and quadratic) models were those which best predicted lamb weight in the pre-weaning phase. Because they exhibited similar predictive characteristics, accuracy and precision, any one of them can be used in the prediction of the growth curves of these animals. The linear model was selected due to its simplicity of interpretation and ease of estimation (Kopuzlu et al., 2014).

The predictive capacity shown by the linear model may be associated with the short period evaluated (less than 100 days of life), when compared with the total estimated life of the lambs. In fact, in the first months of life, these animals are highly efficient in weight gain, which decreases only when the animal reaches sexual maturity due to the reduction in protein deposition and the consequent increased deposition of fat in the empty body (Urbano et al., 2017). Therefore, the inflection of the growth curve of sheep only occurs after they reach sexual maturity (Kopuzlu et al., 2014), at ages older than those evaluated here.

When the effect of sex on the growth curve of the lambs was analyzed, a difference $(P<0.05)$ was seen between the curves of males and females. Thus, separate equations were created to predict the weight of males (weight $(\mathrm{kg})=3.519( \pm 0.086)+0.167( \pm 0.002)$ * age) and females (weight $(\mathrm{kg})=3.266( \pm 0.086)$ $+0.158( \pm 0.002)$ * age) (Figure 1). Similar results (differences between the growth curves of different sexes) were also observed by Sarmento et al. (2006), who adjusted growth curves for adult Santa Inês sheep by the Gompertz model, and by Kopuzlu et al. (2014), who used a Brody model to adjust growth curves for males and females of wool breeds.

The estimated weights for each sex (Figure 1) demonstrate superiority of males over females, especially after the first 40 days of life. Although females mature earlier in most species, growth is more accelerated in males due to testosterone (Reddy et al., 2015), where muscle tissue deposition is prioritized over the growth of adipose tissue. Precisely for this reason, males have a greater capacity to convert the consumed feed into body tissue (Pires, Müller, Tonetto, \& Carvalho, 2011). 


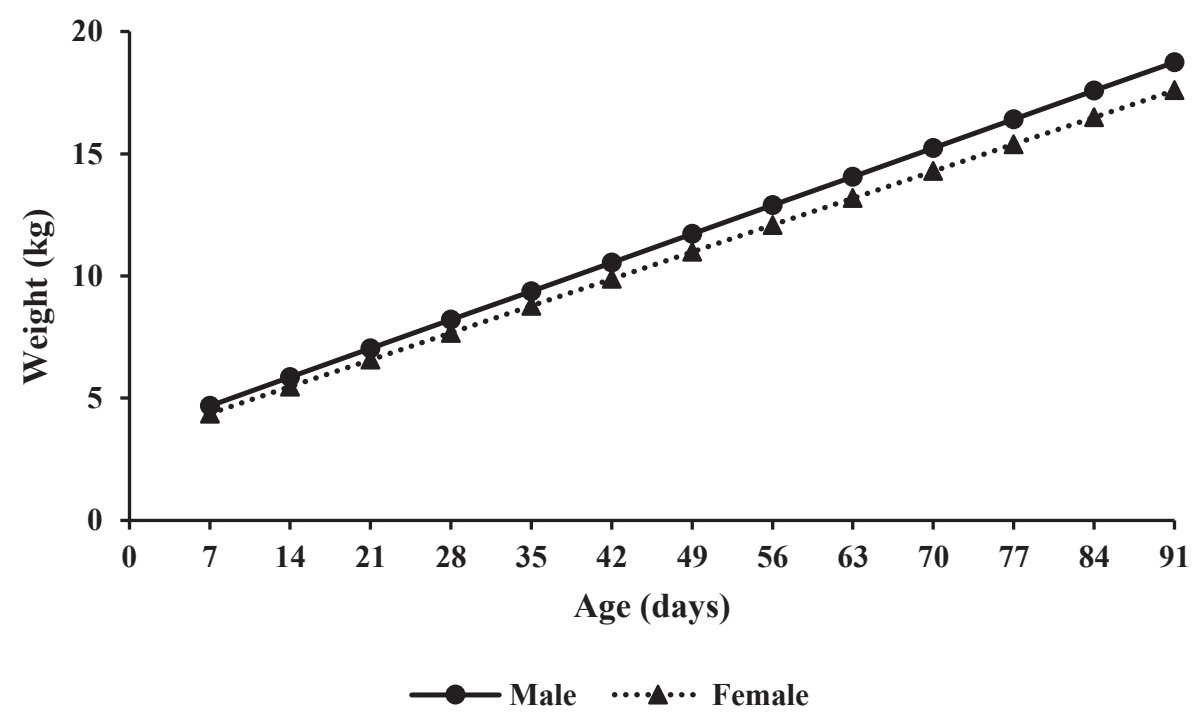

Figure 1. Growth curves projected using the estimated parameters for each sexual condition of lambs during the pre-weaning phase.

In conclusion, the first-degree linear model was the most adequate to describe the growth of sheep in the pre-weaning phase, when males and females showed different growth patterns.

\section{Acknowledgment}

The authors thank the Coordination for the Improvement of Higher Education Personnel - Brazil (CAPES) - Finance Code 001. Thanks are also due to the Federal University of Mato Grosso do Sul, CNPq and the Federal University of Rio Grande do Norte for their support.

\section{References}

Conrado, V. D. C., Arandas, J. K. G., \& Ribeiro, M. N. (2015). Modelos de regressão para predição do peso da raça Canindé através de medidas morfométricas. Archivos de Zootecnia, 64(247), 277-280. doi: 10. 21071/az.v64i247.400

Fernandes, H. J., Tedeschi, L. O., Paulino, M. F., Detmann, E., Paiva, L. S., Valadares, S. C., Fo..... Azevêdo, J. A. G. (2012). Evaluation of mathematical models to describe growth of grazing young bulls. Revista Brasileira de Zootecnia, 41(2), 367-373. doi: 10.1590/ S1516-35982012000200020

Gurgel, A. L. C., Difante, G. S., Emerenciano, J. V., Neto, Roberto, F. F. S., Zaros, L. G., Costa, M. G.,... Ítavo, C. C. B. F. (2020). Impact of supplementation with different protein sources on the parasitological profile of ovine matrices and development of lambs. Bioscience Journal, 36(2), 496-506, 2020. doi: 10.14393/BJ-v36n2a2020-39823

Hermuche, P. M., Maranhão, R. L. A., Guimarães, R. F., Carvalho, O. A., Jr., Gomes, R. A. T., Paiva, S. R., \& McManus, C. (2013). Dynamics of sheep production in Brazil. International Journal of Geo-Information, 2(1), 665-679. doi: 10.3390/ijgi2030665 
Kopuzlu, S., Sezgin, E., Esenbuga, N., \& Bilgin, O. C. (2014). Estimation of growth curve characteristics of Hemsin male and female sheep. Journal of Applied Animal Research, 42(2), 228-232. doi: 10. 1080/09712119.2013.84247

Oliveira, A. P., Pereira, E. S., Pinto, A. P., Silva, A. M. A., Carneiro, M. S. S., Mizubuti, I. Y.,... Gadelha, C. R. F. (2014). Estimates of nutritional requirements and use of small ruminant nutrition system model for hair sheep in semiarid conditions. Semina: Ciências Agrárias, 35(4), 1985-1998. doi: 10.5433/1679-0359.2014v35n4p1985

Pires, C. C., Müller, L., Tonetto, C. J., \& Carvalho, S. (2011). Effect of birth type and sex on performance and carcass characteristics of lle de France $x$ Texel crossbred lambs. Revista Ceres, 58(4), 432-437. doi: 10. 1590/S0034-737X2011000400005

Reddy, R. C., Amodei, R., Estill, C. T., Stormshak, F., Meaker, M., \& Roselli, C. E. (2015). Effect of testosterone on neuronal morphology and neuritic growth of fetal lamb hypothalamus-preoptic area and cerebral cortex in primary culture. Plos One, 10(6), e0129521. doi: 10.1371/journal. pone.0129521

Regazzi, A. J. (2003). Teste para verificar a igualdade de parâmetros e a identidade de modelos de regressão não-linear. Revista Ceres, 50(287), 9-26.

Ribeiro, E. L. A., \& García, E. G. (2016). Indigenous sheep breeds in Brazil: potential role for contributing to the sustainability of production systems. Tropical Animal Health and Production, 48(1), 1305-1313. doi: 10.1007/s11250-016-1109-3
Sarmento, J. L. R., Regazzi, A. R., Sousa, W. H., Torres, R. A., Breda, F. C., \& Menezes, G. R. O. (2006). Analysis of the growth curve of Santa Ines sheep. Revista Brasileira de Zootecnia, 35(2), 435-442. doi: 10.1590/ S1516-35982006000200014

Souza, D. A., Selaive-Villarroel, A. B., Osório, C. S., \& Teixeira, A. (2013). Growth performance, feed efficiency and carcass characteristic of lambs produced from Dorper sheep crossed with Santa Inês or Brazilian Somalis sheep. Small Ruminant Research, 114(1), 51-55. doi: 10.1016/j. smallrumres.2013.06.006

Souza, J. S., Difante, G. S., Emerenciano, J. V., Neto, Lana, A. M. Q., Roberto, F. F. S., \& Ribeiro, P. H. C. (2019). Biometric measurements of Santa Inês meat sheep reared on Brachiaria brizantha pastures in Northeast Brazil. Plos One, 14(7), e0219343. doi: 10.1371/journal. pone. 0219343

Tedeschi, L. O. (2006). Assessment of the adequacy of mathematical models. Agricultural Systems, 89(2-3), 225-247. doi: 10.1016/j.agsy.2005.11.004

Urbano, S. A., Ferreira, M. A., Rangel, A. H. N., Lima, D. M., Jr., Andrade, R. P. X., \& Novaes, L. P. (2017). Lamb feeding strategies during the pre-weaning period in intensive meat production systems. Tropical and Subtropical Agroecosystems, 20(1), 49-63.

Vieira, P. A. S., Pereira, L. G. R., Azevêdo, J. A. G., Neves, A. L. A., Chizzotti, M. L., Santos, R. D.,... Chaves, A. V. (2013). Development of mathematical models to predict dry matter intake in feedlot Santa Ines rams. Small Ruminant Research, 122(1-3), 78-84. doi: 10.1016/j.smallrumres.2012.10.007 
